\title{
WATER SAVING WITH THE USE OF DIFFERENT IRRIGATION SYSTEMS UNDER EGYPTIAN CONDITIONS
}

\author{
Morad, M.M. ${ }^{1}$ E.I. A. Abdel-Aal ${ }^{2}$ and, M.A.M. Moursy ${ }^{3}$.
}

\section{ABSTRACT}

The performance of three different irrigation systems (drip, sub-surface and sprinkler irrigation) in terms of actual irrigation water requirements, crop yield, water use efficiency and water saving was experimentally investigated under condition of sugar-beet planting in sandy soil.

Water saving through the use of the three irrigation systems was studied as a function of change in water regime (100, 75 and 50\%) and planting dates (1 Oct., 20 Oct. and 10 Nov.).

Water saving was also recorded in the case of planting using compost comparing with the case of planting with no compost.

The experimental results reveal to the following:

-The highest amount of water saving was recorded under the use of sub-surface irrigation system with 50\% water regime in the case of using compost and with delaying planting date to $10 \mathrm{Nov}$.

- The highest values of crop yield and water use efficiency were found under the use of drip irrigation system with 100\% water regime in the case of using compost and at 1 Oct. planting date.

Keywords: irrigation systems, sugar-beet, water regime, planting date, compost, water saving

\section{INTRODUCTION}

$\mathrm{W}$ ater is the source of life on Earth for all living organisms. Water is the second most important of all natural resources on Earth next to air as its quantities are fixed, whether it is

\footnotetext{
${ }^{1}$ Prof. of Agric. Eng., Fac. of Agric., Zagazig University.

${ }^{2}$ Assist. Prof. of Agric. Eng., Fac. of Agric., Zagazig University.

${ }^{3}$ Assist. Researcher, Water Management Research Inst., N.W.R.C.
} 
fresh water, salt water, surface water or underground water. Water resources in Egypt are becoming scarce. Surface-water resources originating from the Nile are now fully exploited, while groundwater sources are being brought into full production. Egypt is facing increasing water needs, demanded by a rapidly growing population, by increased urbanization, by higher standards of living and by an agricultural policy which emphasizes expanded production in order to feed the growing population.

The amount of water used for agriculture has declined slowly during the past decade, it still accounts for the largest share (84\%) or 49.7 billion $\mathrm{m}^{3}$ per year. This amount does not include an annual estimated loss of 2 billion $\mathrm{m}^{3}$ due to evaporation from irrigation systems, annual evapotranspiration losses are estimated at 34.8 billion $\mathrm{m}^{3}$. The government has launched a national program for irrigation improvement and water management. Surface irrigation systems were used in most cultivated lands of the Nile Valley and Delta witch have low efficiency.

Economic use of water is a vital problem which confronts farmers and agricultural scientists in irrigated areas of arid and semi-arid regions. Knowledge of the right amounts of irrigation water is essential to obtain economically maximum yields of different crops.

Irrigation water management involves determining when to irrigate, the amount of water to apply at each irrigation event and during each stage of plant, and operating and maintaining the irrigation system.

Irrigation systems are selected, designed and operated to supply the irrigation requirements of each crop on the farm while controlling deep percolation, runoff, evaporation, and operational losses, to establish a sustainable production process.

Several studied have been conducted to determine the effect of irrigation systems on water saving. Sakellariou et al. (2002) evaluated the surface and sub-surface drip irrigation application effects on sugar-beet crop performance, under two levels (100 and 80\%) of water application depth and found that the subsurface drip irrigation leaded to greater yield and higher sugar yield making significant water saving compared to surface drip irrigation. Hanson and May (2004) obtained yield increases when drip system were used compared to the sprinkler systems with similar 
amounts of applied water; additionally, drips systems reduced percolation below the root zone. Perry et al. (2009) found that drip systems generally use half as much water as furrow irrigation. Mevhibe et al. (2010) found that drip irrigation in sugar-beet production allows saving in input use more than sprinkler and furrow irrigation systems and that it increases productivity and profit. The spread of especially drip irrigation in sugar-beet production has increased the economic use of water and profitability, through savings in input and reduction of costs.

On the other hand, to achieve the goal of water saving Ali et al. (2007) stated that water saved by deficit irrigation can be used to irrigate more land (on the same farm or in the water user's community), which given the high opportunity cost of water may largely compensate for the economic loss due to yield reduction. Lytle et al. (2008) found that deficit irrigation was feasible for corn, sunflowers, and soybeans crops. This research showed reduction of $15 \%$ of the corn yields for a saving of $17.78 \mathrm{~cm}$ when compared to full irrigation. Topak et al. (2011) studied the effect of deficit irrigation treatments $(75,50$ and $25 \%$ of full irrigation) on sugar-beet (Beta vulgaris L.) yield and water use efficiency (WUE). And found WUE was the highest in DI25\% irrigation conditions and the lowest in full irrigation conditions. The results revealed that irrigation of sugar-beet with drip irrigation method at 75\% level (DI25) had significant benefits in terms of saved irrigation water and large WUE, indicating a definitive advantage of deficit irrigation under limited water supply conditions.

Another ways for water saving are by changing the crop planting date and by the compost application. Mamo (2000) reported that compost application increased the water holding capacity at the field capacity and at the permanent wilting point but did not change the available water capacity. Ghanem and Ebaid (2001) reported that increasing organic manure significantly increased saved water, water use efficiency, yield and its components. Andrew (2008) determined planting date (mid-April (early), late May (mid), and mid-June (delayed)) influenced crop and water use (WU of barley. Early planting resulted in excellent forage yields. Water use was higher for the first planting date than for the second and third dates. Abdou et al. (2011) studied the effects of three 
sowing dates $\left(\mathrm{D}_{1}\right.$ : $1^{\text {st }}$ June, $\mathrm{D}_{2}: 15^{\text {th }}$ June and $\mathrm{D}_{3}$ : $1^{\text {st }}$ July) on yield of sunflower. The results indicated that the sowing date treatments significantly affected seed yield. The highest seed yield were obtained from $1^{\text {st }}$ of June sowing however, July $1^{\text {st }}$ sowing date gave the lowest values. The highest water use efficiency was obtained from $\left(D_{1}\right)$ treatment. Farsiani et al. (2011) studied the effect of sowing date $\left(4^{\text {th }}\right.$ May, $24^{\text {th }}$ May, $13^{\text {th }}$ June and $3^{\text {rd }}$ July) on yield and yield components and seed sugar content in sweet corn and found that, the $3^{\text {rd }}$ of July treatment (control) will be the best date for quantitative yield, this sowing date maybe very useful for water saving.

It is clear from the above literature review that water saving can be achieved by using modern irrigation systems. There are also many ways for water saving as implementation of deficit irrigation practices, changing crop planting date and application of compost.

\section{So, the objectives of this research are to:-}

- Study the effect of different irrigation systems and water regimes on water saving and crop yield.

- Study the effect of sugar-beet planting dates and use of compost rates on water saving and crop yield.

\section{MATERIALS AND METHODS}

Field experiments were carried out in open field conditions during the season of 2011-2012 at Wadi EL-Natrown on Farm Irrigation Department Research Station, Water Management and Irrigation Systems Research Institute, El-Bohera Governorate.

The soil physical and chemical properties of the experimental plots were determined according to [Klute, 1986 and Page, et al. 1982 ] shown in Table (1).

The irrigation water was obtained from local well. The irrigation water has a $\mathrm{pH}$ of 7.14 and total soluble salts of $755 \mathrm{ppm}$. Sodium adsorption ratio value was 12.1 .

\section{Materials}

\section{The irrigation systems}

Three irrigation systems were installed in the experimental area. The three irrigation systems contains the following general components: 
- Pump: An electrical centrifugal pump is used with $44.1 \mathrm{~kW}$ engine power and a discharge of $100 \mathrm{~m}^{3} / \mathrm{h}$ at 4 bar operating pressure.

- Control head consists of (centrifugal pump, pressure regulator, pressure gauges, flow meter and filters).

- Pipe network consists of main, sub-main lines, secondary lines and manifold (160 mm diameter PVC is used for main line, between 90 and 110mm PVC for sub-main line, between $63-75 \mathrm{~mm}$ for secondary lines between 63-50 $\mathrm{mm}$ for manifold line).

Table (1): Physical and chemical analysis of the experimental field during 2011 and 2012 seasons.

\begin{tabular}{|c|c|c|c|c|c|c|c|c|c|c|}
\hline \multirow{2}{*}{$\begin{array}{l}\text { Soil } \\
\text { layer } \\
(\mathrm{cm})\end{array}$} & \multicolumn{3}{|c|}{ Particle size distribution $\%$} & \multirow{2}{*}{ 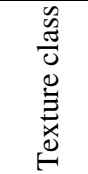 } & \multirow{2}{*}{$\begin{array}{c}\text { Field } \\
\text { capacity } \\
(\%)\end{array}$} & \multirow{2}{*}{$\begin{array}{c}\text { Wilting } \\
\text { point } \\
(\%)\end{array}$} & \multirow{2}{*}{$\begin{array}{l}\text { Available } \\
\text { water (\%) }\end{array}$} & \multirow{2}{*}{$\begin{array}{c}\text { Bulk } \\
\text { density } \\
\left(\mathrm{g} / \mathrm{cm}^{3}\right)\end{array}$} & \multirow{2}{*}{$\begin{array}{c}\text { EC } \\
(\mathrm{ds} / \mathrm{m})\end{array}$} & \multirow[t]{2}{*}{ PH } \\
\hline & Sand & Silt & Clay & & & & & & & \\
\hline $0-20$ & 94.5 & 3.5 & 2.0 & \multirow{3}{*}{ Sandy } & 13.25 & 5.5 & 7.75 & 1.65 & 1.45 & 8.23 \\
\hline $20-40$ & 95.0 & 3.3 & 1.7 & & 14.25 & 4.9 & 9.35 & 1.56 & 1.55 & 8.11 \\
\hline $40-60$ & 95.7 & 3.0 & 1.3 & & 14.50 & 4.3 & 10.2 & 1.44 & 1.65 & 7.97 \\
\hline
\end{tabular}

- Drip irrigation system have lateral drip-lines GR that are made of polyethylene pipes with $16 \mathrm{~mm}$ diameters, $25 \mathrm{~cm}$ dripper distance, 3.51 lit/h dripper discharge at 1.35 bar operating pressure and $60 \mathrm{~cm}$ between laterals. Fig. (1) showed the layout of drip irrigation system.

- Sub-surface irrigation system have lateral with leaky pipe porous flexible rubber hose $16 \mathrm{~mm}$ diameter with flow rate of $1.55 \mathrm{lph} / \mathrm{m}$ at 1.55 bar operating pressure and $60 \mathrm{~cm}$ between laterals. Lateral leaky pipes were installed at $15 \mathrm{~cm}$ under the soil surface and the distance between laterals $60 \mathrm{~cm}$. Fig. (1) showed the layout of sub-surface irrigation system

- Sprinkler irrigation system have lateral lines that are made of PVC pipes with $50 \mathrm{~mm}$ diameters, $12 \mathrm{~m}$ sprinkler distance, sprinkler riser 0.75 inch diameter, $1.25 \mathrm{~m}$ high, rotating sprinklers $1.9 \mathrm{~mm}$ out diameter and $2.2 \mathrm{~m}^{3} / \mathrm{h}$ discharge under operating pressure of 2.2 bar. Fig. (2) showed the layout of sprinkler irrigation system.

\section{The cultivated crop}

Sugar-beet Beta vilgarus (Samba) was sown at the rate of $5 \mathrm{~kg} / \mathrm{fed}$ and hand planted at $3-5 \mathrm{~cm}$ depth on $25 \mathrm{~cm}$ planting space and $60 \mathrm{~cm}$ between rows with two seeds per hill on 1/10/2011. Thirty five days from seeding, the seedling was thinned to one plant per hill. It is worthy to 
mention that irrigation treatments took place after the thinning stage. Application of irrigation scheduling treatments started after the initial stage of crop. Calcium super phosphate at $\left(15.5 \% \mathrm{P}_{2} \mathrm{O}_{5}\right)$ at the rate of 100 $\mathrm{kg} / \mathrm{fed}$ was added during field preparation. Nitrogen fertilization (ammonium nitrate $33.5 \% \mathrm{~N}$ ) at the rate of $200 \mathrm{~kg} / \mathrm{fed}$ was added and divided on 5 times the first one after thinning and the 4 times between the time and times 15 days. Potassium sulphate $\left(48 \% \mathrm{~K}_{2} \mathrm{O}\right)$ was added at a rate of $50 \mathrm{~kg} / \mathrm{fed}$ on 2 times with nitrate.

\section{Methods}

\section{Experemintal coditions}

Experiments were carried out as a function of change in the following parameters.

Irrigation systems, three irrigation systems were used for irrigating sugar-beet crop (Sprinkler, drip and sub-surface irrigation).

Water regimes, three water regimes were studied as follow:

100, 75 and 50\% of actual irrigation water requirements

Planting dates, sugar-beet crop was cultivated at three dates as follows:

1 Oct, 20 Oct and 10 Nov.

Use of compost, sugar-beet crop was treated as follows:

With compost (added at rate of 5 ton/fed) and no compost.

\section{Measurements and calculations}

Evalution of the above mentioned experemintal parameters was carried out taking into consederation the following indicators:

\section{Actual irrigation water requirements}

The amount of actual irrigation water requirements under each irrigation system was calculated according to James (1988) by using the following equation:

$$
I R a=\frac{[(F C-\theta) \times d]+L R}{E s}
$$

Where:

$\mathrm{IRa}=$ total actual irrigation water requirements ( $\mathrm{mm} /$ intervals)

$\mathrm{FC}=$ soil moisture content at field capacity $(\%)$

$\theta \mathrm{v}=$ soil moisture content $(\%)$ under soil condition.

$\mathrm{d}=$ depth of soil layer $(20 \mathrm{~cm}$ for the initial stage and $30 \mathrm{~cm}$ for the last stage).

Es $=$ system efficiency $(\%)$.

LR =Leaching requirements was calculated according to Droonbos and Pruitt (1977) using the following equation: 

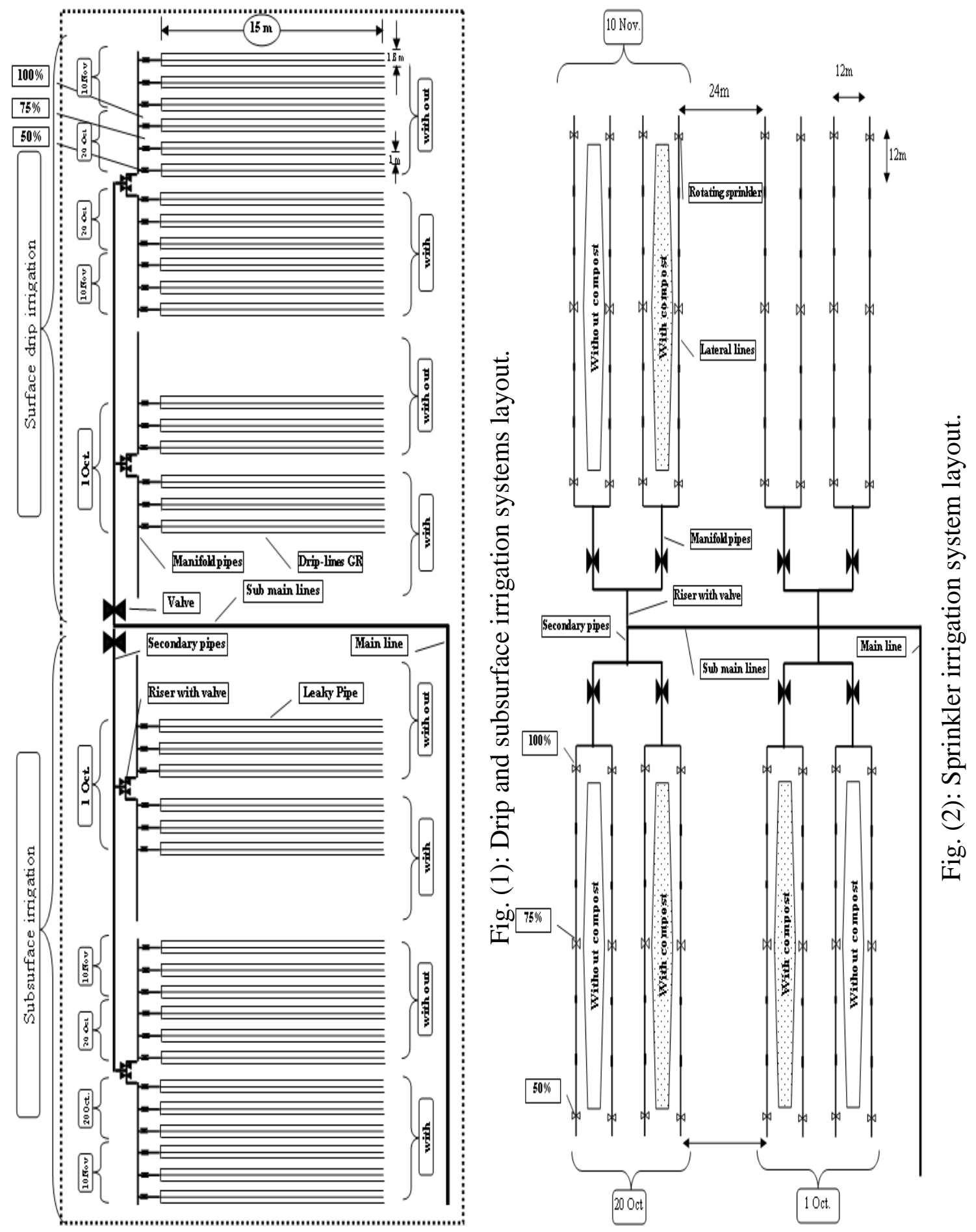


$$
\mathrm{LR}=\frac{\mathrm{ECW}}{5 \mathrm{ECe}-\mathrm{ECW}}
$$

Where:

$\mathrm{ECw}=$ Electric conductivity for irrigation water $(\mathrm{dS} / \mathrm{m})$

$\mathrm{ECe}=$ Electric conductivity of soil required suiting certain productivity deficit $(\mathrm{dS} / \mathrm{m})$.

\section{Crop yield}

- Root yield (Meg/fed).

- Sugar yield $(\mathrm{Meg} / \mathrm{fed})=$ root yield $(\mathrm{Meg} / \mathrm{fed}) \times$ sucrose $\%$.

\section{Water use efficiency}

Water use efficiency (WUE) was calculated for both root yield and sugar yield according to Jensen (1983), as follows

$$
\begin{aligned}
\mathrm{WUE}_{\text {root yiled }} & =\frac{\text { root y ield }(\mathrm{kg} / \mathrm{fed})}{\text { actual irrigation water requirments }\left(\mathrm{m}^{3} / \mathrm{fed}\right)}, \mathrm{kg} / \mathrm{m}^{3} \\
\mathrm{WUE}_{\text {sugaryield }} & =\frac{\text { sugar y ield }(\mathrm{kg} / \mathrm{fed})}{\text { actual irrigation water requirments }\left(\mathrm{m}^{3} / \mathrm{fed}\right)}, \mathrm{kg} / \mathrm{m}^{3}
\end{aligned}
$$

\section{Water saving}

The water saving per every treatment was calculated by the follows formula:

$$
\text { Water saving }\left(\mathrm{m}^{3} / \mathrm{fed}\right)=\mathrm{Rwr}-\mathrm{IRa}
$$

Where: $\quad$ Rwr $=$ recommended water requirements.

\section{RESULTS AND DESCUTION}

\section{1- Total actual irrigation water requirements.}

The total actual irrigation water requirements to sugar-beet under all treatments are shown in Fig. (3).

Concerning the irrigation systems, the obtained data revealed that the total actual irrigation water requirement for sub-surface irrigation is lower than that for drip irrigation and sprinkler irrigation. While the highest total actual irrigation water requirements was remarked with the use of sprinkler irrigation under all treatments. By using sub-surface irrigation system the total actual irrigation water requirement decreased by 21.2 and $5.3 \%$ compared with sprinkler and drip irrigation systems respectively at $100 \%$ water regime under planting date 1 Oct. and with the use of compost.

Concerning water regimes, the obtained results show that the water regime plays an important role to reduce total actual irrigation water 
requirements. Increasing water regime from 50 to 75 and $100 \%$ the total actual irrigation water requirements increased by 36.45 and $73 \%$ using drip irrigation system under planting date of 1 Oct. and with the use of compost.

Relating to the planting date, data show that by delaying the planting date to 20 Oct and 10 Nov., the total actual irrigation water requirements decreased by 6.8 and $14.3 \%$ compared to 1 Oct. using sprinkler irrigation system under $100 \%$ water regime and with the use of compost.

As to the effect of compost application on total actual irrigation water requirements, results show that the use of compost increased the water holding capacity of the soil. With compost the total actual irrigation water requirements decreased, vice versa without compost the value increased by $5 \%$ using sub-surface irrigation system under planting date 1 Oct. and $100 \%$ water regime.

\section{Crop yield}

Fig. (4), show the root yield as well as sugar-beet yield under all treatments.

Relating to the irrigation system, data show that drip irrigation system has high value of root yield, while the sub-surface irrigation system has low value under all treatments. Drip irrigation system increased the root yield by 20.5 and $44.6 \%$ compared with sprinkler and sub-surface irrigation system under planting date 1 Oct., $100 \%$ water regime and with the use of compost.

With regard to the effect of water regime on root yield, applying amount of water equal to $50 \%$ water regime caused reduction for root yield under all treatments. It is clear that increasing the applied irrigation water, resulted in increasing root yield under all treatments. The highest value of root yield was scored from $100 \%$ water regime, while the lowest value of root yield was gained from 50\% water regime under different treatments.

The root yield increased by about 29.4 and 70.3, 17.6 and 45.5 and 34.7 and $77.4 \%$ when applying $100 \%$ water compared with applying 75 and $50 \%$ under sprinkler, drip and sub-surface irrigation systems under planting date 1 Oct. and with the use of compost. These results go parallel with those obtained by Abd El-Wahab et al. (1996). 


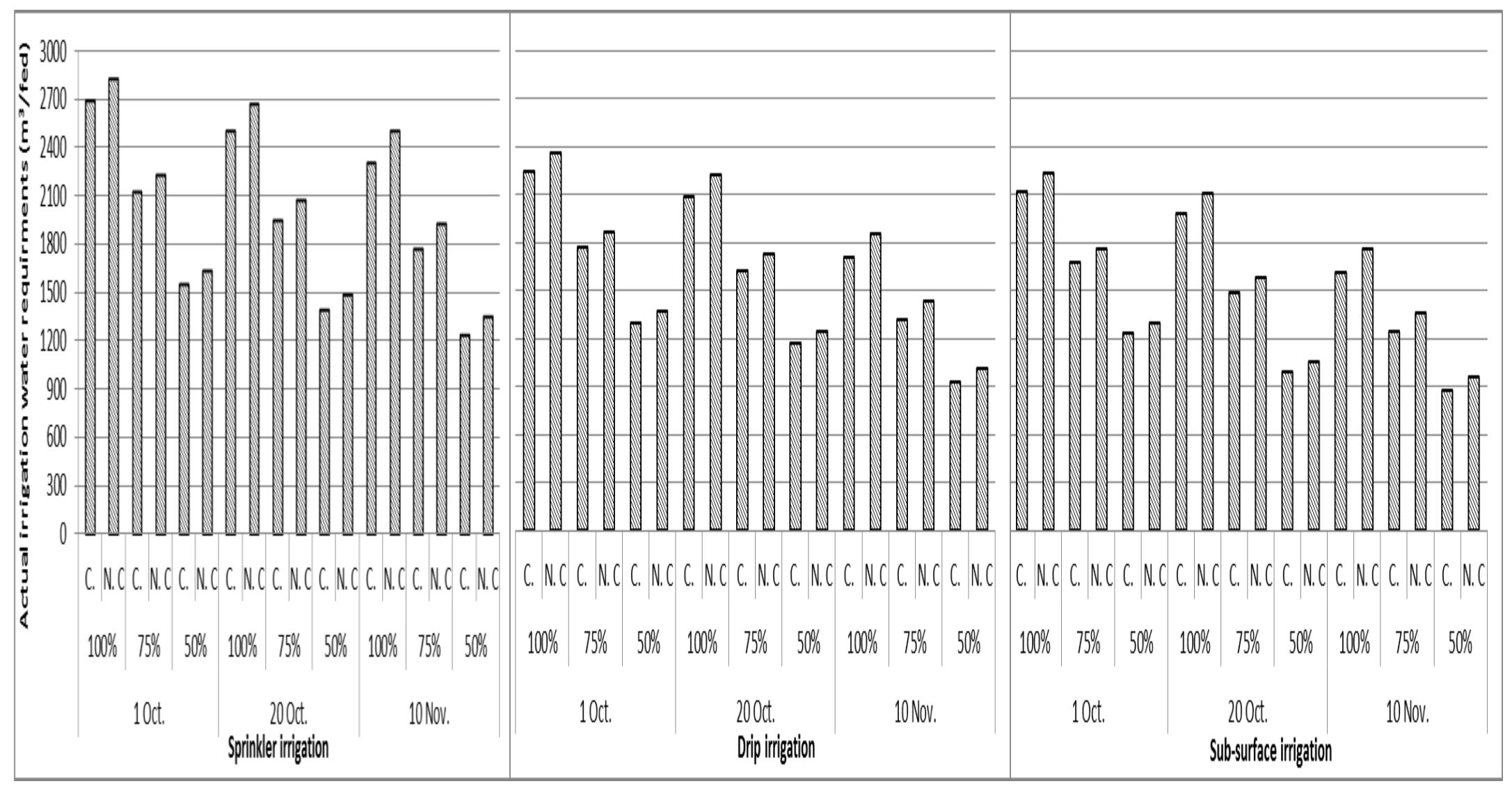

Fig. (3): Effect of irrigation systems on actual irrigation water requirements under different treatments.

$$
\text { C : Compost N. C. }=\text { No compost }
$$


Concerning the planting date, data show that changing planting date affects the root yield, by delaying the planting date from 1 Oct. to 10 Nov. the root yield reduced by 24.4, 22.4 and $27.7 \%$ using sprinkler, drip and sub-surface irrigation systems respectively, under $100 \%$ water regime and with the use of compost.

As to applying compost, the obtained results show that the used compost increased the root yield compared with no compost under all treatments. The highest values of the root yield were 17.7, 21.4 and $14.8 \mathrm{Meg} / \mathrm{fed}$, while the lowest values were 15.4, 19.1 and $12.8 \mathrm{Meg} / \mathrm{fed}$ under sprinkler, drip and sub-surface irrigation systems respectively, with planting date 1 Oct. and $100 \%$ water regime. The use of compost increased the yield by 15.6, 12.1 and $15.6 \%$ compared with no compost under sprinkler, drip and sub-surface irrigation systems respectively, with planting date 1 Oct. and $100 \%$ water regime.

Concerning the effect of irrigation systems on sugar yield, it is obvious from the results show in Fig. (4), that sugar yield was increased when sugar-beet subjected to irrigate with drip irrigation system either in the sprinkler and sub-surface irrigation system, and the reduction in sugar yield were more pronounced with irrigated by sub-surface irrigation system under all treatments. Moreover, the highest sugar yield was 4.51 $\mathrm{Meg} / \mathrm{fed}$ when sugar-beet irrigated by drip irrigation system under planting date 1 Oct. and $100 \%$ water regime with the use of compost. While the lowest value was $1.1 \mathrm{Meg} / \mathrm{fed}$ when sugar-beet irrigated by sub-surface irrigation system under planting date 10 Nov., 50\% water regime and with no compost.

Relating to the effect of water regime on sugar yield, sugar yield increased by more than 62.6, 39.3 and $72.3 \%$ with increasing applied water from 50 to $100 \%$ using sprinkler, drip and sub-surface irrigation systems under 1 Oct. planting date and with the use of compost. These results are similar to those found by Cucci and Caro (1986) who reported that irrigation increased sucrose yield by 39\%. Similar results were found by Abd El-Wahab et al. (1996).

Regarding the planting date, results show that the planting date 10 Nov. reduced the sugar yield to 2.45, 3.33 and $2.05 \mathrm{Meg} / \mathrm{fed}$ compared with 2.89, 3.81 and 2.45 and 3.54, 4.51 and 3.27 Meg/fed under 1 and 20 Oct. 
using sprinkler, drip and sub-surface irrigation systems respectively, under $100 \%$ water regime and with the use of compost. Planting date 20 Oct. increased the sugar yield by $18.2,14.3$ and $11.5 \%$ compared with 10 Nov., while reduced the value by 15.4, 19.1 and $12.8 \%$ compared with 1 Oct. under sprinkler, drip and sub-surface irrigation systems, respectively, with $100 \%$ water regime and with the use of compost.

As to the application of compost, data show that the use of compost increased the sugar yield, while without compost the sugar yield reduced under all treatments.

\section{Water use efficiency.}

The amount of water used to produce $1 \mathrm{~kg}$ of root yield or $1 \mathrm{~kg}$ of sugar yield under the condition of this experiment is shown in Fig. (5). The lower the amount of water used to produce $1 \mathrm{~kg}$, the higher the WUE.

The results indicated that higher WUE values of both root and sugar yield were 11.37 and $2.66 \mathrm{~kg} / \mathrm{m}^{3}$ was obtained under drip irrigation system, while the sprinkler irrigation system treatments induced lower values 6.7 and $1.4 \mathrm{~kg} / \mathrm{m}^{3}$ under planting date 1 Oct., $50 \%$ water regime and with the use of compost. In general the results lead to the conclusion that, the greatest values were obtained under drip and sub-surface irrigation systems and the lowest values was recorded with used sprinkler irrigation system. Similar trend was obtained by (Chartzoulakis and Michelakis 1988).

Considering the water regime, the results indicated that the values of WUE for root yield were 6.61, 9.56 and 6.98, 6.48, 10.3 and 5.56 and $6.71,11.34$ and 6.8 and were $1.32,1.33$ and 1.4, 2.37, 2.24 and 2.66 and $1.54,1.48$ and $1.55 \mathrm{~kg} / \mathrm{m}^{3}$ for sugar yield for treatments 100,75 and $50 \%$ under sprinkler, drip and sub-surface irrigation systems, respectively with planting date 1 Oct. and with the use of compost.

Relating to the planting date, data obtained that the values of WUE of root and sugar yield affected by delaying planting date under all treatments. 1 Oct. has the highest WUE, the values were 6.61 and 1.32, 9.56 and 2.37 and 6.98 and $1.54 \mathrm{~kg} / \mathrm{m}^{3}$ were found under sprinkler, drip and sub-surface irrigation systems, under $100 \%$ water regime and with the use of compost.

The values of WUE increased gradually with the use of compost compared to with no compost. The increase reached up to 22.3 and 

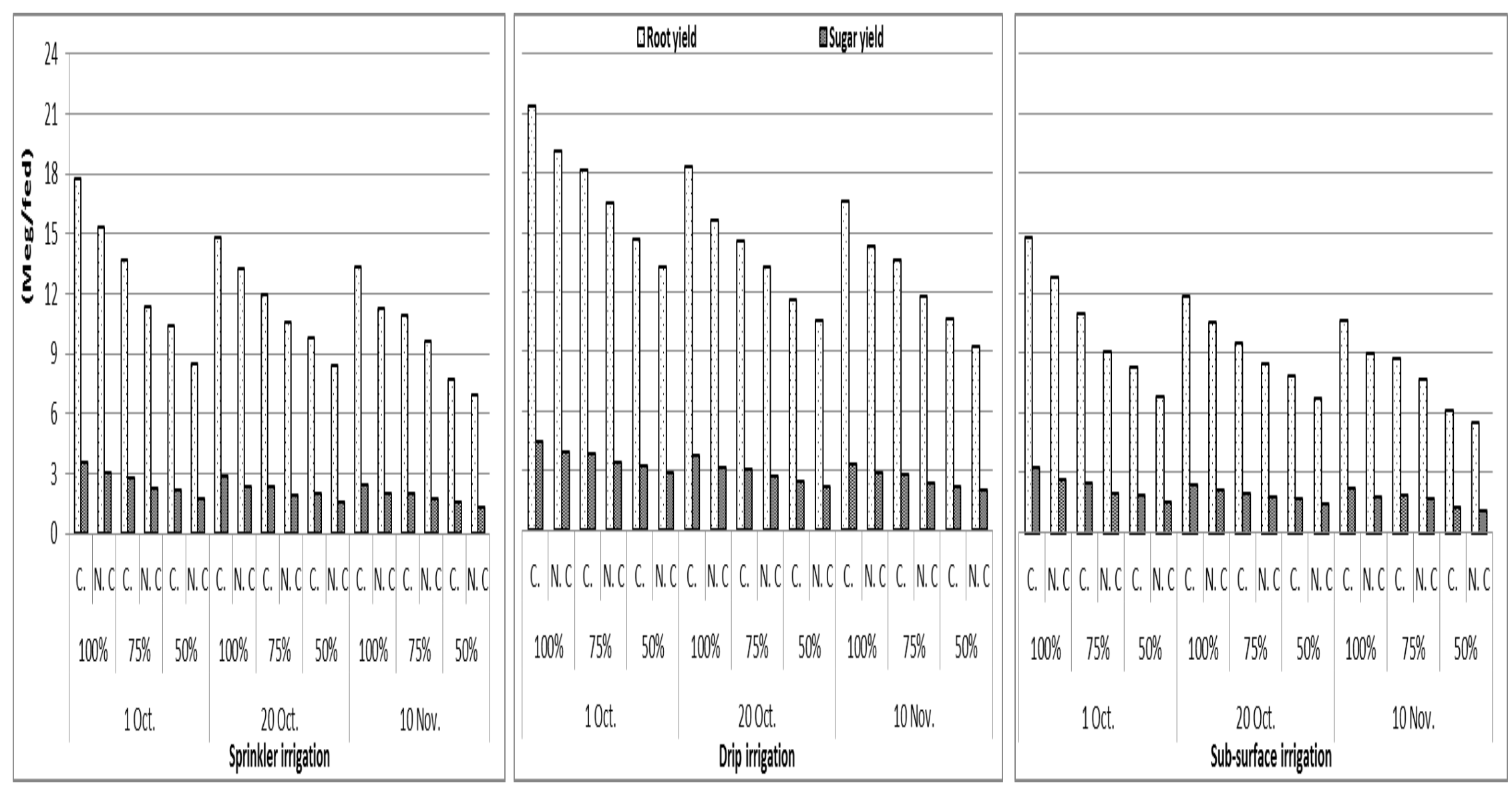

Fig. (4): Effect of irrigation system on root and sugar yields under different treatments. 
$17.4 \%$ for both root and sugar yield, respectively compared with the use case of no compost under all treatments. These results are in harmony with those reported by Awad (1998).

\section{Water saving}

The data in Fig. (6) showed that the water saving under the different treatments compared with the actual irrigation water requirements 3000 $\mathrm{m}^{3} /$ fed Fig. (6) showed that all the treatments saved water.

Considering the effect of irrigation systems on water saving, results show that the highest value of water saving was obtained under sub-surface irrigation system, comparing with drip and sprinkler irrigation systems. While the lowest value of water saving was obtained under sprinkler irrigation system.

As to the effect of water regime on water saving, results show that water regime saved water. $100 \%$ water regime decreased the water saving by 64.2, 38.2 and 33.7 and 78.2, 55.3 and 50.4\% compared with 75 and $50 \%$, under sprinkler, drip and sub-surface irrigation systems, respectively with the use of compost and 1 Oct. planting date.

Regard with the planting date, the data show that delaying planting date from 10 Nov. increased the water saving by $40.3,41.8$ and 35.4 and 121.5, 70.1 and 57.6\% compared with planting date 20 and 1 Oct. under sprinkler, drip and sub-surface irrigation systems, respectively with $100 \%$ water regime and with the use of compost.

The results also indicated that higher water saving was found by using compost, vice versa the lowest value was recorded in the cases of no compost under all treatments, because the compost increased the water holding capacity in the soil.

\section{CONCLUSION}

The experimental results indicated the following conclusion:-

-Drip irrigation system achieved the highest values of root and sugar yields, while sprinkler irrigation recorded the lowest values. On the other hand sucrose $\%$ increased with use sub-surface irrigation system.

-Using water regime of $50 \%$ decreased both root yield and sugar yield compared with $75 \%$ and $100 \%$.

- The highest value of total actual irrigation water requirements was found under planting date of 1 Oct. but the lowest value was found under planting date of 10 Nov. The results indicated that delaying planting date 

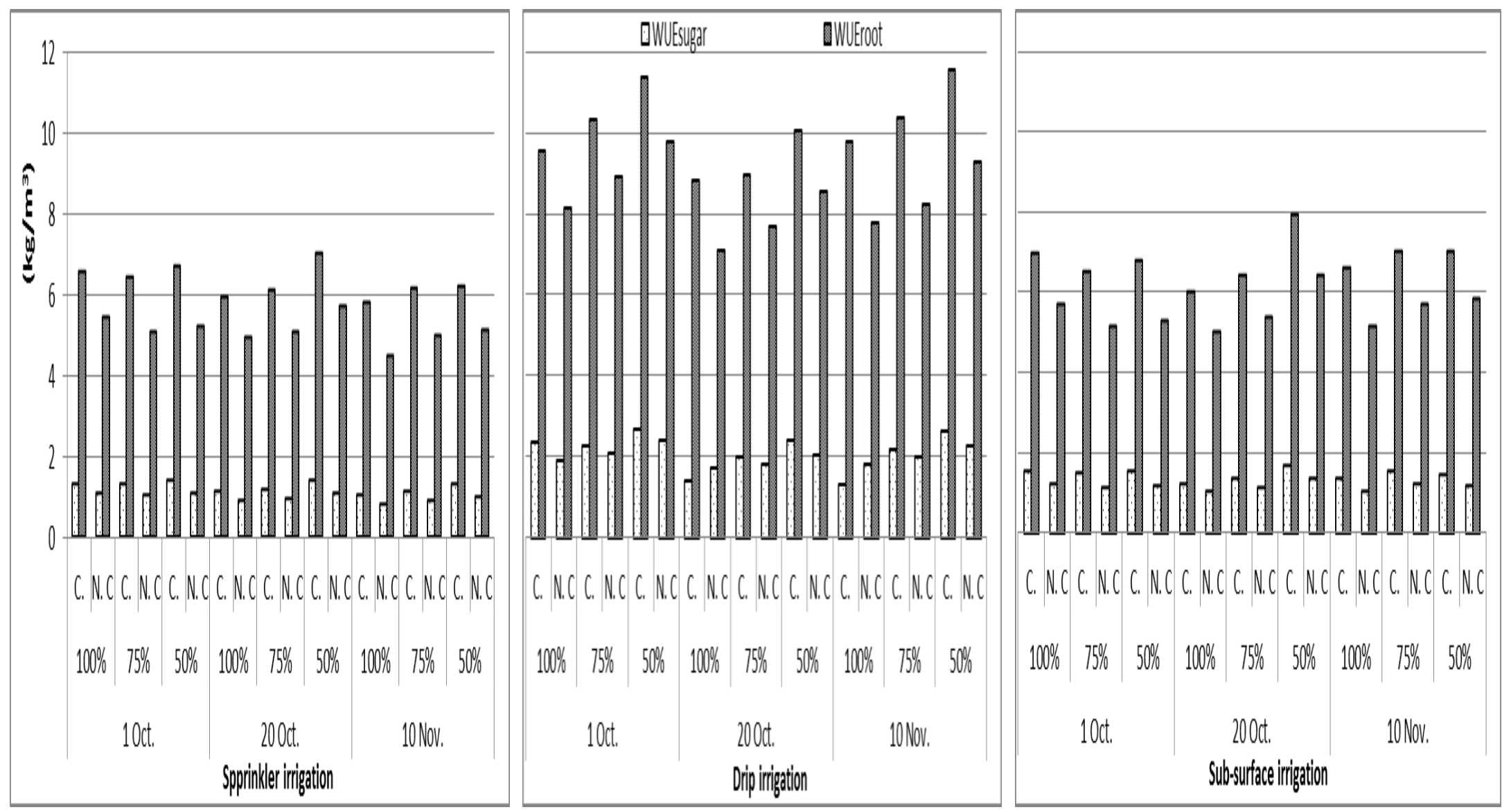

Fig. (5) Effect of irrigation systems on WUE under different treatments. 

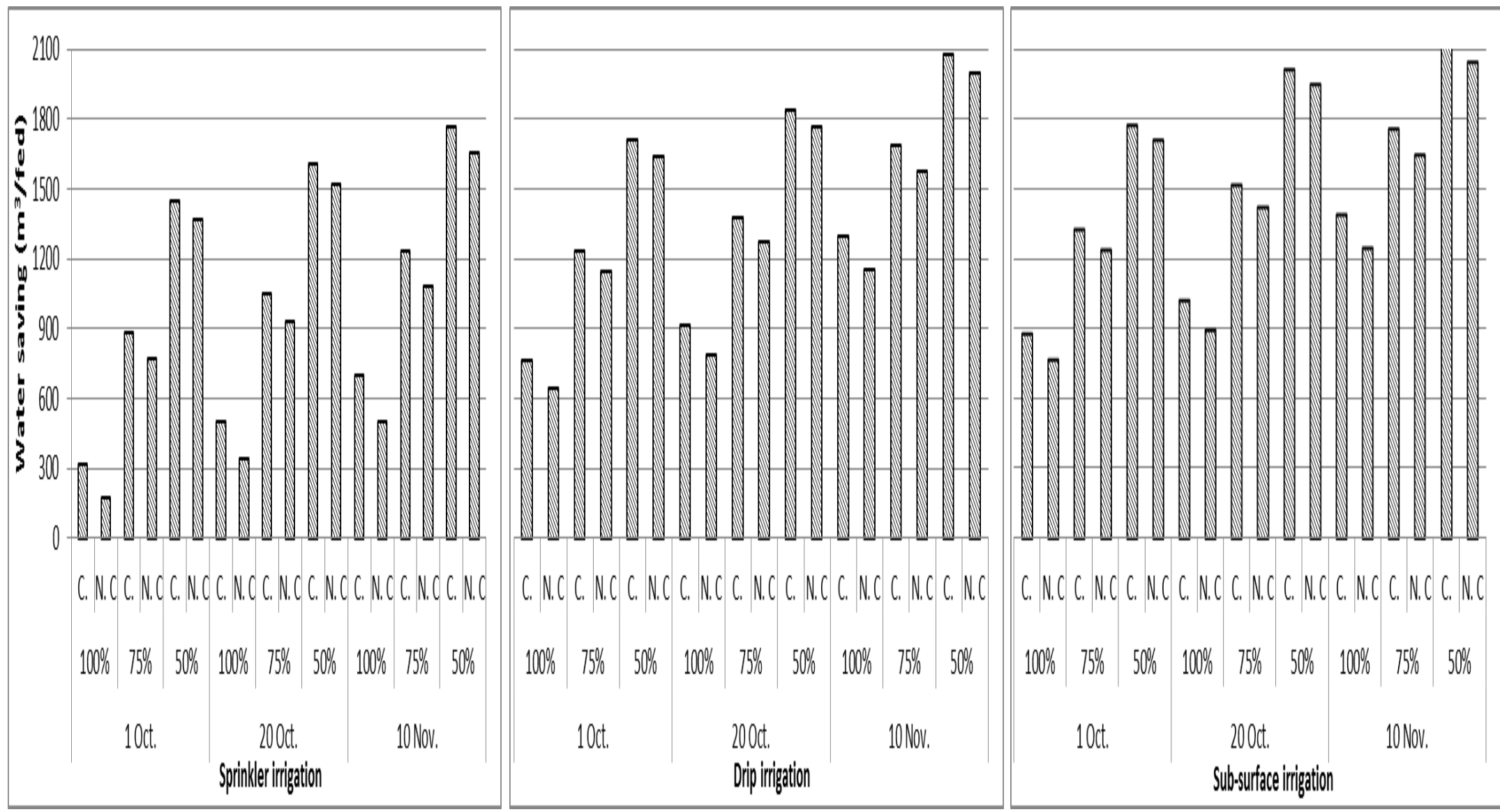

Fig. (6) Effect of irrigation system on water saving under different treatments. 
to 10 Nov. decreased root and sugar yields compared with 1 and 20 Oct.

- Also, results indicated, that with using compost the yield of root and sugar and water saving increased comparing with the case of no compost.

Generally, it could be concluded that, under similar conditions, using drip irrigation system, $100 \%$ water regime, 1 Oct. planting date and the use of compost to achieve the highest yield, WUE and water saving.

\section{REFERENCES}

Abd El-Wahab, S. A., A. A. Amer, M. I. El-Shahawy and M.M. Sobh (1996). Effect of different irrigation amounts and polassium fertilizer rates on yield and quality of sugar-beet and water efficiencies (1996). J. Agric. Sci. Mansoura Univ. Vol. 21 No. (12): 4687- 4699.

Abdou, S. M. M. , K.M. Abd El- Latif, R. M. F. Farrag and K. M. R. Yousef (2011). Response of Sunflower Yield and Water Relations to Sowing Dates and Irrigation Scheduling Under Middle Egypt Condition. Adv. Appl. Sci. Res., 2 (3):141-150.

Andrew W. L. (2008). Planting date and Preplant Weed management Influence Yield, Water Use, and Weed Seed Production in Herbicide-Free Forage Barley. Weed Technology 22:486-492.

Awad,Y.H.(1998). Newly reclaimed soil and wheat yield as affected by FYM and gypsum under different irrigation regimes. Zagazig J.Agric.Res.25(4):671-677.

Chartzoulakis, K. S. and N. G. Michelakis (1988). Influence of different irrigation systems in greenhouse tomatoes. Acta. Hort. (228): 97-104.

Cucci, G. and A. de Caro (1986). Impact of irrigation on productivity of autumn - sown sugar-beet in Italy. Institute de Agron colivazloni erbascee dell Univ. di Bari, Bari, Italy. Irrigation Drenaggio, Vol.33 (4): 29-32. (C.F. irrigation and drainge Abst. 13-1332, 1987). 
Doorenbos, J. and Pruitt (1977). Crop Water Requirements, Irrigation \& Drainage Paper (24), FAO, Rome.

Farsiani, A., Mohammad-Eghbal Ghobadi and Saeid JalaliHonarmand (2011). The effect of water deficit and sowing date on yield components and seed sugar contents of sweet corn (Zea mays L.). African Journal of Agric. Research Vol. 6(26) : 5769-5774.

Ghanem S.A and R.A. Ebaid (2001). Effect of farm yard manure and water regims on productivity of rice and succeeding clover crop. Egypt. J. Appl. Sci., 16 (6): 115-128.

Hanson, B. and D. May (2004). Effects of subsurface drip irrigation on processing tomato yield, water table depth, soil salinity, and profitability. Agric. Water Manage. 68:1-17.

James, L. G. (1988). Principles of farm irrigation system design, Krieger publishing company, Krieger Drive, Malabar, Florida.

Jensen, M.E. (1983). Design and operation of farm irrigation systems. ASAE, Michigan, USA., pp: 827.

Klute, A. (1986). Methods of Soil Analysis. Part-1: Physical and Mineralogical Methods. ( $2^{\text {nd }}$ ed.) American Society of Agronomy, Madison, Wisconsin, U.S.A.

Lytle, B., N. Hansen, F. Jaeger and J. Nikkel, (2008). A win-win scenario for urban/rural water supplies. The Water Report, Issue \#48.

Mamo, M. (2000). The effect of MSW compost application on soil water and water stress in irrigated corn. Compost Science \& Utilization, 8, 236-246.

Mevhibe A, E. Gunes and B. Gulcubuk. (2010). The effects of irrigation methods on input use and productivities of sugar-beet in Central Anatolia, Turkey. African J. of Agric. and Resource Economics, Vol. 5, Issue 3, 188-195. 
Page, A. L., R. H. Miller and D. R. Keeney (1982). Methods of soil Analysis. Part-2: chemical microbiological properties. (2nd ed.). American Soc. of Agron., Madison, Wisconsen, U.S.A.

Perry, C., P. Steduto, R. G. Allen and C. M. Burt (2009). "Increasing productivity in irrigated agriculture: Agronomic constraints and hydrological realities." Agric. Water Management, (96): 15171524.

Sakellariou-makrantonaki M., D. Kalfountzos and P. Vyrlas (2002). water saving and yield increase of sugar-beet with subsurface drip irrigation. Global Nest: the Int. J. Vol. 4, No. 2-3, 85-91.

Topak R., S. Su“heri and B. Acar (2011). Effect of different drip irrigation regimes on sugar-beet (Beta vulgaris L.) yield, quality and water use efficiency in Middle Anatolian, Turkey. Irr. Sci. 29:79-89.

\section{الملخص العربى}

\section{ترشيا المياه باستخدام نظم الرى المختلفة تحث الظروف المصريه}

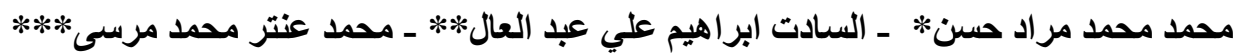

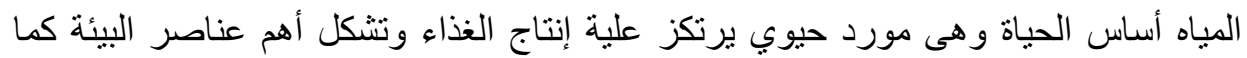

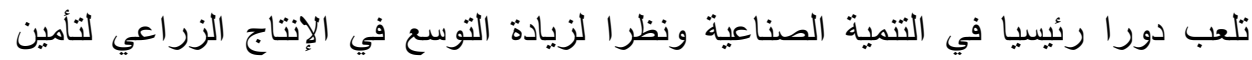
الاحتياجات الغذائية المتز ايدة لسكان مصر ، فان ذلك يتطلب استخدام وادارة جيدة للموارد المائية

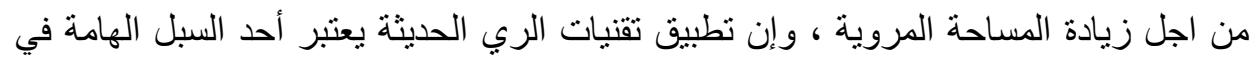

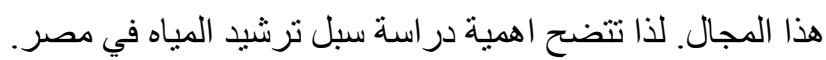

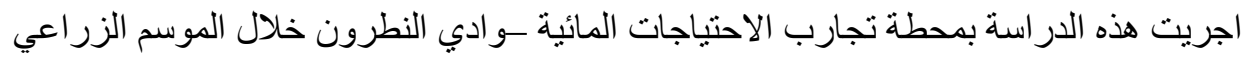

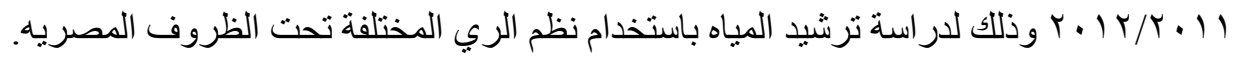

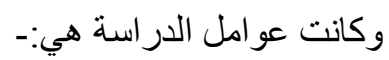
( ) ثلاثة نظم ري مختلفة ( الرى بالرش - الرى بالتنقيط - الرى تحت السطحى)

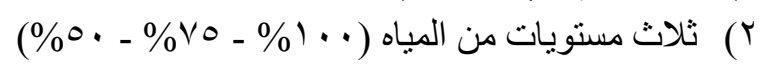

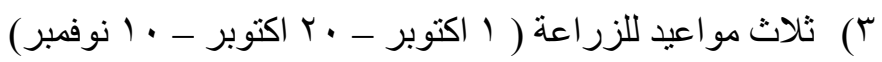

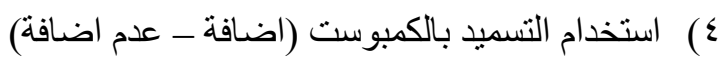

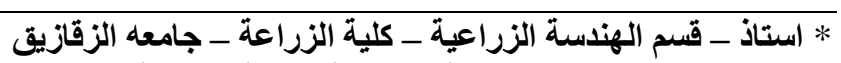

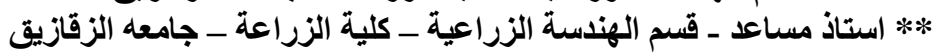

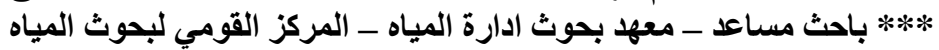


وتم قياس الاداء اخذا في الاعتبار كلا من ( الاحتياجات المائية ـ انتاج الجذور - انتاج السكر -

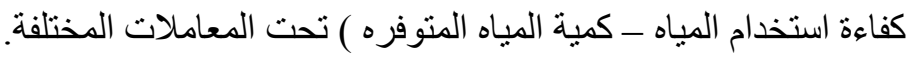
وقد اظهرت النتائج ما يلي:-

1 - ان اقل قيم من كميات الري المضافة كانت تحت كلا من الري تحت السطحي مع استخدام

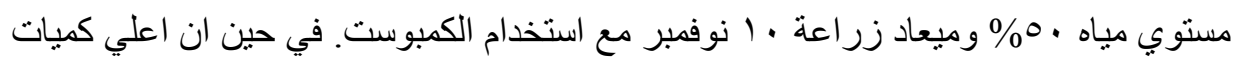

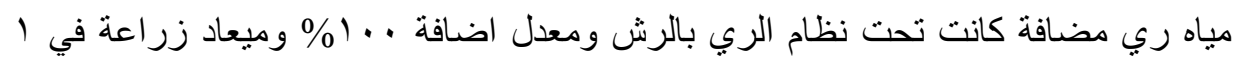
اكتوبر مع عدم اضافة كمبوست.

r- كان اعلي انتاجية لكلا من الجذور و السكر تحت نظام الري بالتنقيط مع استخدام كمية مياه

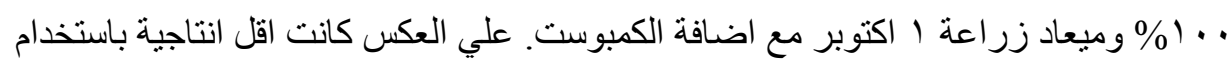

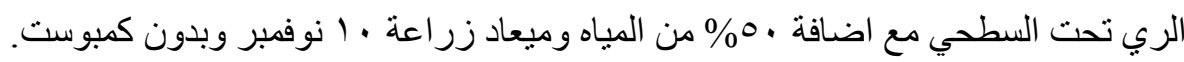
rـ كانت اعلي قيم لكفاءة استخدام المياه تحت نظام الري بالتنقيط يليه الرش ثم تحت السطحي. ــ ـ واشارت النتائج الي ان افضل نظام ري استخدم لتوفير المباه كان الري تحت السطحي ثم

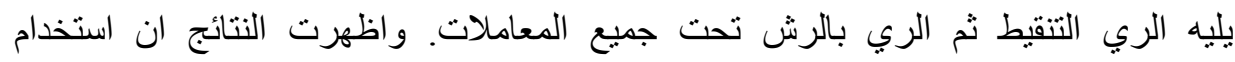

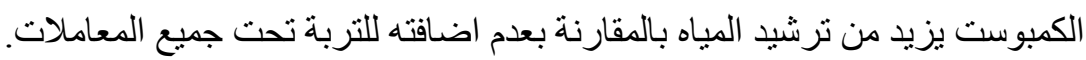

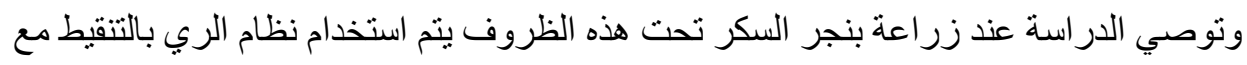

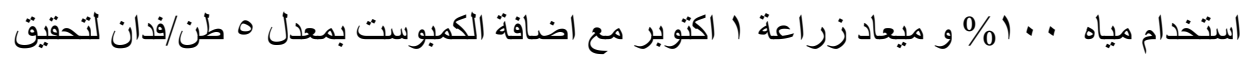
اعلي النتائج من حيث الانتاجية وكفاءة الاستهلاك المائي وترشيد المباد المياه 